\title{
Patient Groups and the Construction of the Patient-Consumer in Britain: An Historical Overview
}

\author{
ALEX MOLD \\ Centre for History in Public Health, Department of Public Health and Policy, London School \\ of Hygiene and Tropical Medicine, Keppel Street, London WC1E 7HT \\ email: Alex.Mold@lshtm.ac.uk
}

\begin{abstract}
This article presents an historical overview of the changing meaning of the patientconsumer, and specifically the role played by patient groups in constructing the patient as consumer. It is argued that patient groups were central to the formation of the patient-consumer, but as health consumerism was taken on by the state, they lost control of this figure. Competing understandings of what it meant to be a patient-consumer developed, a shift that raises further questions about the unity of claims made in the name of the patient-consumer.
\end{abstract}

The figure of the patient has loomed large in recent attempts to reform the National Health Service in Britain. According to the NHS Plan of 2000, 'The health and social care system must be shaped around the needs of the patient, not the other way round' (Department of Health, 2000). Since 2000, a series of government documents and initiatives emphasised the importance of patient 'choice' and patient 'voice' in developing and improving NHS services (Department of Health, 2000, 2004, 2006, 2007, 2008, 2009). New Labour politicians asserted that such policies were developed in response to wider shifts within society. The then Secretary of State for Health, Alan Milburn, told the Fabian Society in 2001 that 'People grow up today in a consumer society. Services whether they are private or public - succeed [or] fail according to their ability [to] respond [to] modern expectations' (Milburn, 2001). Milburn (and other key New Labour figures) justified the need for radical reform of the health service by asserting that the NHS had failed to keep up with the pace of social change, and as a result insufficient attention had been paid to what patients wanted.

By locating NHS reform within the context of a consumer society, Milburn brought together the figure of the patient with that of the consumer. Yet the New Labour government was by no means the first to talk openly about the 
patient as consumer or to develop policies with him or her in mind. Indeed, the idea that patients could be thought of as consumers has played an explicit role in British health policy since at least the 1970s. This can be seen in areas such as the attempt to develop more consumer-friendly hospital complaints procedures through the Davies Committee in 1973, and the establishment of the Community Health Councils in 1974, which were specifically designed to represent the consumer in local health services (DHSS, 1973). Caution should be exercised, however, about making direct linkages between apparent signs of consumerism in the health service of the 1970s and New Labour's more recent reforms of the NHS. The meaning of consumerism within health policy, and with it the construction of the patient-consumer, has altered significantly over time. This article will investigate the historical origins of the patient-consumer, and track changes in the definition and meanings ascribed to this figure from the 1960 s to the 2000s. Particular attention is paid to the part played by groups that attempted to represent the views of patient-consumers. During this period there was a rapid rise in the number of voluntary organisations, with some of the most significant growth being seen among groups that worked in the interest of individuals suffering from a specific disease (Wood, 2000). But there were also organisations that attempted to represent all patients, regardless of the condition that they had or the population group that they belonged to. The interests of the patient-consumer were taken on by groups such as the Patients Association (established in 1963) and also by the organised consumer movement in the form of the Consumers' Association (1956), the National Consumer Council (1975) and the College of Health (1983). By representing the patient away from the politics of specific diseases, these groups played a key role in the construction of the generic 'patient-consumer'.

However, patient groups were by no means the only influence on the development of the patient-consumer, nor did such organisations provide the sole or even dominant understanding of this figure. Governments of various political persuasions also became involved in attempting to define what it meant to be a patient-consumer. From the early 1960s, until the election of Margaret Thatcher's Conservative government in 1979, there was considerable political interest in the notion of 'participation'. Nascent consumerism within public services was encouraged as a way of enhancing public participation and democracy in the planning and delivery of services. Such ideas fell away during the 1980s, as the Conservative government sought to introduce the voice of the consumer to public services but through other agents, principally general managers and fund-holding GPs. This was a time of 'consumerism by proxy', where choices were made on the behalf of patient-consumers, rather than by individuals themselves. In the 200os, even more emphasis was placed on listening to the 'patient voice' within healthcare, and there was a proliferation in the number of groups claiming to represent the patient-consumer. Such developments clearly had implications for 
the ongoing construction of the patient-consumer, and also the continued ability of patient groups to speak for him or her.

Of course, the making of the patient-consumer over the last 40 years was not a process unique to Britain. The term 'consumer' also entered the health discourse in other English-speaking countries during the 1960s and 1970s (Irvine, 2002; Tomes, 2006). In Europe, too, the patient-consumer began to make an appearance, with patient groups coalescing around the notion of patients' rights (van der Zeijden, 2000). Indeed, a global dimension to patient consumerism has been present since at least the 1970s, when the international consumer movement took on issues of concern to patients such as monitoring the actions of the pharmaceutical industry and the marketing of breast milk substitutes (Hilton, 2009). But despite the global positioning of the patient-consumer, he/she remains a deeply contested figure, more accepted within some health systems than others (Baggott and Forster, 2008). National contexts thus remain important, and providing a case-study of how the patient-consumer came into being in one country helps to illuminate similarities and differences between nations over the patient-consumer.

Drawing on the papers and publications produced by patient-consumer groups, as well as government documents, this article will present an historical overview of the shifting meaning of the patient-consumer in Britain, but also attempt to unravel the extent to which patients themselves were involved in driving such change. It will argue that the patient-consumer was constructed both by patient-consumer groups and by government, a process which produced competing ideas about what it meant to be a patient-consumer. Patient organisations played a key role in building up the patient-consumer in the late 1960 s and 1970s, but towards the end of the 1980s they lost control of this figure as patient consumerism was reformulated by the Conservative government. The increasing marketisation of public services during the 1990 s resulted in greater emphasis being placed on the individual patient-consumer. This led to a fragmentation of collective attempts to represent patient-consumers, forcing patient-consumer groups to adopt a reactive rather than proactive stance. By considering such shifts in detail, this article will point to the mutability of patient consumerism, a contention reinforced by an examination of the historical roots of the patient-consumer.

\section{Patient consumerism before the patient-consumer? Situating the emergence of the patient-consumer}

Patients could be said to have operated as consumers long before the term 'consumer' was widely used in the context of health. Prior to the creation of the NHS in 1948, a 'medical marketplace' existed and patients, as a result of the 'power of the purse', were able to exercise control over their healthcare (Jenner 
and Wallis, 2007; Porter, 1985). Private patients were not passive individuals, but were instead often willing to question diagnosis and treatment, and to shop around if unhappy with the care they received (Wilde, 2009; Digby, 1994). Even when individuals did not pay physicians directly, as in the case of the hospital contributory schemes of the early twentieth century, patients were afforded some say in how health care was managed (Gorsky et al., 2006). Echoing the participatory mechanisms of trades unions and co-operatives, contributors were represented on hospital governing bodies through worker-governors elected from each contributing workplace or district. Worker-governors were able to put forward patients' concerns over issues such as waiting times, visiting rights, poor treatment and the quality of accommodation (Gorsky, 2008). Other forms of patient involvement before 1948 included the oversight of GPs by friendly societies, and also the local democratic processes which surrounded the provision of municipal health services (Gorsky, 2007). Such mechanisms clearly provided a more collective form of patient participation in healthcare than could be found within private practice, where individuals negotiated with doctors directly.

However, these early forms of patient involvement were not generally described using the language of consumption or consumerism. As John Brewer and Frank Trentmann have pointed out, 'People do a lot of consuming without necessarily thinking about themselves as consumers, but at certain historical moments they can also acquire a voice and identity as consumers' (Brewer and Trentmann, 2006: 1). Moreover, the participatory mechanisms that had been part of health care provision before 1948 were largely swept away when the NHS came into being. Ministerial oversight and parliamentary scrutiny were believed to provide a sufficient level of democratic control over the NHS (Gorsky, 2007). Patients themselves had no direct say in the way services were run.

Specific engagement with the idea that patients were 'consumers' of health care only began to occur in the later half of the twentieth century, as the proliferation of consumer goods and the development of the organised consumer movement started to have an impact on the delivery of public services (Hilton, 2003; Trentmann, 2006). The influence of consumerism has been considered in the context of distinct sectors, such as housing (Shapely, 2006) and analysed in terms of particular elements of a consumerist approach, such as the notion of 'choice' (6, 2003; Greener and Powell, 2008; Greener, 2003, 2009). However, historical scrutiny of consumerism within the health service has largely been confined to broad overviews (Pickstone, 2000; Smith, 2005) or more specific topics such as the rise and fall of the Community Health Councils (Hogg, 2009). There is a large contemporary social science literature that dealt with the impact of consumerism as it made its mark on healthcare in the 1970s, 1980s and 1990s, and this work can be used to help trace the dominant trend in thought about consumerism in health during each period. Yet there have been few attempts to systematically map the changing dynamics of consumerism within the health 
service from the 1960 s to the present. This article seeks to begin to fill this gap.

Using the social science and medical literature as an historical source actually provides a clue as to when the notion of the patient as 'consumer' first began to gain currency in the health field. A literature search of British medical and social science journals reveals that a sustained engagement with the notion of patients as consumers started in the 1960 s. One of the earliest references appeared in a Lancet editorial published in 1961, entitled 'Patients as consumers: wants and needs'. This piece considered the findings of a survey by Political and Economic Planning (a body connected to the organised consumer movement) on what people thought about health and welfare services (Anon, 1961). A further editorial, published one year later, pointed to the growing activity by consumer groups around healthrelated topics (Anon, 1962). The connection of the term 'patient-consumer' with the work of consumer groups suggests that these organisations played a key part in introducing the language of consumption, and specifically the notion of the patient as consumer, to the discourse around health. Yet the appearance of the patient-consumer was not merely a semantic shift, but was instead representative of wider changes in relationships between doctors and patients, and between patients and health care providers and policy-makers. Developing notions of patient autonomy and of social citizenship gave rise to greater demands for patient participation within the NHS.

\section{The era of participation: autonomy and citizenship, 1963-79}

The emergence of the patient-consumer should be located not just in the growth of the organised consumer movement and its expanding interests, but also in changing social attitudes and hierarchies. The late 1960s and early 1970 s witnessed a 'backlash against professional society', bringing into question the power and authority of the professions, including medicine (Perkin, 1990). The further problematisation of medical authority by sociologists and others helped to challenge paternalistic assumptions within healthcare, allowing for the emergence of more critical, patient-led (rather than doctor-led) organisations. At the same time, there were also a number of scandals which further undermined the public's trust in the medical profession. These involved specific treatments, such as the prescription of thalidomide to pregnant women, but also more general systems of care, especially for long-stay hospital patients (Stacey, 1974). Although public satisfaction with the NHS in general remained high - Political and Economic Planning (PEP) reported that 86 per cent of patients surveyed in 1961 were satisfied with their GP - questions were increasingly being raised about the authority of medical professionals and the standards of service offered (PEP, 1961). In particular, patients were expressing a greater desire for information about their condition: Ann Cartwright's 1964 survey for the Institute of Community 
Studies found that 23 per cent of hospital patients were unable to find out all they wanted to know about their condition (Cartwright, 1964). One way in which discontent with services manifested itself was in the establishment of organisations to campaign for, and provide, improvements (Deakin, 1995). The public were demanding better services but, by creating their own groups, also demonstrated a desire for a role in deciding how these were shaped.

Partly as a reaction to such developments, political interest in the concept of public participation grew in the 1960 s and 1970s. The government began to recognise that post-war improvements had been achieved at the cost of an over-centralised state, and a series of initiatives was launched to improve public participation, such as the Town and Country Planning Act of 1968 (Fielding, 2003). There were also attempts to involve the 'consumer' in public services. Consumer councils had previously existed in the nationalised industries, but the establishment of the government-funded National Consumer Council (NCC) in 1975 marked a more determined shift towards taking the consumer voice within public services seriously. The NCC was concerned with speaking for consumers in both the public and private sectors, using the language of consumerism to enhance public participation (Hilton, 2003). These ideas were also being applied to the NHS, where there was a 'rising tide of expectation regarding community participation in health service affairs' (Webster, 1996: 486). Moreover, participation was (at least to some extent) seen as being synonymous with consumerism: Malcolm Johnson noted that 'Whether this patient involvement is an expression of consumerism is perhaps a semantic debate. Certainly it has every appearance of being part of that movement' (Johnson, 1977: 93).

Looking at activities of patient groups, however, would suggest that there was no single vision of the form that consumerism in health should take. Two slightly different conceptions of the patient-consumer were put forward by these organisations: firstly, as an autonomous individual, able to determine the fate of his/her own body; and, secondly, as a citizen-taxpayer who had a right to determine how services should be provided. The notion that the patientconsumer was an autonomous individual was articulated most clearly by the Patients Association (PA). The PA was founded in 1963 by Helen Hodgson, a teacher. Hodgson set up the organisation following the publication of an article by the doctor, Maurice Pappworth, which revealed that NHS patients were routinely being used in medical experiments without their knowledge or consent (Pappworth, 1962). Although patients were supposed to give their consent to participate in medical trials (following the Nuremberg Code), this was widely ignored (Hazelgrove, 2002). Indeed, at the time consent for procedures was rarely sought, patients were not always told what condition they were suffering from or what their prognosis was, and they had little input into decisions about treatment. For Hodgson, the key issue was that the patient 'is entitled to know what treatment, if any, he is receiving' (Hodgson, 1963: 1339). The PA maintained 
that the patient was not just able to decide what should happen to his or her body, but that he or she had an absolute right to do so. This argument was underpinned by a belief in patient autonomy and individual self-determination.

Autonomy was at the heart of many of the 'new social movements' of the 1960s, and was particularly crucial to the challenges mounted against medical paternalism by patient-consumer groups such as the PA. Although an explicit link between autonomy and consumerism within health was not necessarily made by the PA and other organisations, a sense of patient autonomy was crucial to the formation of the patient-consumer. While there are many different ways of defining the 'consumer' (Gabriel and Lang, 2006) and this has changed over time (Trentmann, 2006), some degree of autonomy, and particularly the ability to choose, was central to the notion of the consumer as a rational actor developed by consumer groups such as the Consumers' Association from the late 1950s onwards (Hilton, 2003). Reflecting these ideas, a specific image of the patient as an autonomous consumer began to emerge through the work of groups such as the PA.

In tandem with the development of the notion of the autonomous patient, a slightly different idea of what it meant to be a consumer of health care also came into being during the early 1960s. This view of the patient-consumer was more closely tied to ideas about citizenship and social rights. Although the National Health Service Act (1946) was framed around the duty of the Minister of Health to provide a comprehensive service, not the right of the patient to receive this, patients began to see the provision of health and welfare as a right: part of the post-war social contract between state and citizen. Reflecting on her admission to hospital in the early days of the NHS, the sociologist Margaret Stacey commented: 'I and others like me were fully aware that we had every right to be there, that we paid through our taxes according to our means and that what treatment we had depended on our condition alone: it wasn't charity: it was as of right' (Stacey, 1999). The idea that, as taxpayers, citizens had certain rights within healthcare was further developed by the Research Institute for Consumer Affairs (RICA), an off-shoot of the Consumers' Association. RICA contended that 'the adult "consumers" whom the National Health Service sustains as patients are also those who maintain it as citizens' (RICA, 1963: 4). As a result, they demanded that the citizen should be 'brought in' to the running and oversight of general practitioner services. Using the language of consumption, RICA called for greater patient participation based on the notion that as a taxpayer the patient had the right not only to receive health care but also to some input into how services should be managed.

This view was partially taken up by the government with the establishment of the Community Health Councils (CHCs). The CHCs grew out of plans to restructure the NHS in the early 1970s, and were intended to provide an element of local democratic accountability within the service (Webster, 1996). This was 
framed in explicitly consumerist terms: the Secretary of State for Health, Sir Keith Joseph, told the House of Commons that the CHCs would be the 'voice of the consumer'. Of course, the establishment of the CHCs must be seen in line with the more general shift towards greater participation in public services discussed above, but it is important to note that an enhanced role for the patient in the health service was something that patient-consumer groups had long been working towards. Patient groups' presentation of the patient-consumer as an individual with the right to participate in discussions about health services suggests that at least some of the initial impetus in shaping ideas about patient consumerism and participation came from these groups. However, the vogue for participation was a temporary one, and by the 1980 s new models of consumerism in health began to take hold.

\section{Quasi-markets and proxy-consumers, 1979-97}

The introduction of a series of policies from the mid-1980s onwards represented a move away from notions of participation and towards the development of proxy-consumers operating within a quasi-market. Conservative social policy in this period was characterised by a desire to 'roll back the state': to limit the direct role of central government in the provision of services, reduce public expenditure and improve the effectiveness of those services that did remain under state control. To this end, various schemes were implemented, underpinned by a desire to reform management structures and encourage the development of markets within public services. The establishment of the NHS Management Enquiry, chaired by Sir Roy Griffiths (managing director of supermarket chain Sainsbury's) in 1983, was indicative of these policies. The Griffiths Enquiry was tasked with developing proposals to make more effective use of resources and improve the management of the NHS. The Griffiths team recommended the introduction of general managers at all levels with the aim of bettering services for the consumer. The enquiry asserted that 'Underlying all that we recommend is the desire to secure the best possible services for the patient.' Griffiths' intention was that 'management plays an active, not merely a reactive, role in relation to patients and the community' (Griffiths, 1983: 175). The implication was that managers, and not just doctors, were to act on the behalf of patients (Harrison, 1994).

The government largely accepted Griffiths' proposals, resulting in the introduction of 'management-led consumerism' within the NHS. This led to a series of attempts to assess how effectively services were being delivered by finding out what consumers thought. Patient satisfaction surveys became common, as did attempts to improve 'customer relations' (Seale, 1993). Critics, such as Fedelma Winkler (Secretary of the Hackney and City CHC), asserted that 'The NHS is now encouraged to see its users in the same way as supermarkets, and so 
health service managers talk about the "customer"' (Winkler, 1987: 1). Yet these 'customers' actually had little direct power or means of exercising choice or voice. Rather, this was to be exercised for them by managers who were to act as a 'proxy-consumer'.

Another kind of proxy-consumer was later proposed by the White Paper, Working for Patients, in 1989. This was an attempt to further restructure the NHS by introducing an internal market within health care. District Health Authorities and 'fund-holding' GPs would be able to purchase healthcare services for their patients from local providers (Department of Health, 1989). Although Working for Patients appeared to place the patient him/herself at the centre of reform, individual patients were not given any additional power to make decisions. The internal market was thus a 'quasi-market', where choices about purchasing health services were delegated to the consumer's agent (a GP or health authority manager) who would act as a 'proxy-consumer' (Le Grand, 1991). However, it is also interesting to note that patient-consumers were themselves operating as proxies: the patient-consumer was a symbolic figure that the government could use to make changes in his or her name. For example, cuts in services could be justified if they were done in the name of the consumer. So patients were to be represented by proxies (doctors and managers) but were themselves also acting as proxies for other concerns.

Looking at the activities of patient-consumer groups in this period would suggest that, while there was support for some reforms, there were organisations which felt that consumers, and not their proxies, should be given more say in decisions about their healthcare. In 1983, the sociologist Michael Young set up the College of Health $(\mathrm{CoH})$. Young had long been involved in consumer affairs - he was instrumental in the establishment of the Consumers' Association and was the first chair of the National Consumer Council - but a period in hospital in the early 1980 convinced him of the need for an organisation for patients to discuss their experiences as consumers of healthcare (Rigge, 1995). The $\mathrm{CoH}$ aimed to provide patients with more information about health and health services, encourage the prevention of disease, facilitate the development of self-help initiatives and improve relationships between patients and health professionals (Self Health, 1983; Young Papers, 1983). By the end of their first year in existence, the College had 10,00o members $(\mathrm{CoH}, 1984)$. The $\mathrm{CoH}$ envisaged a proactive role for the patient-consumer, stating that their aim was 'to give people the information they need to approach the health services as active partners in health care not as passive patients' (CoH, 1984: 1). Information was crucial, director of the $\mathrm{CoH}$, Marianne Rigge, explained, because 'Without information there can be no real choice and I hope that the days are long gone when patients were not expected to exercise choice but rather follow the doctor's orders blindly' (Young Papers, 1986). Young even proposed the introduction of a voucher system for the payment of GPs, something that he believed would emphasise 'the fact that the patient funds the 
money for doctors' salaries from his or her taxes' (Young, 1989: 35). This seems to represent a development of the earlier notion of the patient as citizen-taxpayer, but here the patient-consumer was seen as an individual who was able to make their own decisions about healthcare, rather than allowing his or her doctor to exercise choice on their behalf.

The importance of information and emphasis on the individual were also central to another key aspect of the work of patient groups in this period: the development of patient charters and rights guides. Patient groups had long endeavoured to provide patients with a list of their rights within health care and information about the services available through the NHS (for example, Patients Association, 1974), but in the 1980 os and 1990s there was a proliferation of guides to patients' rights (for example, Consumers' Association, 1980; National Consumer Council, 1983). There were also moves to get these documents codified into a charter, which would clearly establish what patients were entitled to. Charters such as that produced by the Association of Community Health Councils in England and Wales (ACHCEW) in 1986 represented an attempt to draw attention to the rights of the individual patient-consumer in health, but also stressed the more collective nature of rights (ACHCEW, 1986). By setting out what patients were entitled to, charters were intended to empower patient-consumers themselves to make demands on the health service.

There is some evidence to suggest that the Conservative government responded favourably to such an idea. Indeed, the publication of the Department of Health Patient's Charter in 1991 was seen as an emulation of the earlier charters produced by patient groups. The Patient's Charter set out what it described as seven 'well-established' rights and introduced three new ones (Department of Health, 1991). Yet many patient-consumer groups disliked the Patient's Charter, not least because they felt that the government had co-opted their campaigning language (Hogg, 1999). More substantive concerns were put forward by ACHCEW, who argued that the charter should 'do far more to address important issues at the heart of the health service - equality of access to health care, the scope for patient participation on the basis of informed choice and the quality of care and treatment' (ACHCEW, 1996: 1). Young criticised the charter because it lacked 'the means to make the rights effective' (Young, 1991).

Patient-consumer groups' disapproval of the charter can be explained by the different use to which the Patient's Charter was to be put, which was in turn underpinned by an alternative view of the patient-consumer. Critics argued that the rights and standards set out in the Patient's Charter were 'essentially symbolic' and used as a means for indirectly re-imposing central control, in the name of the consumer, on local health care purchasers and providers (Crinson, 1998). The charter was thus a management tool rather than a real attempt to empower patients. Other analysts asserted that the charters produced by the Major government were concerned with protecting the rights of individuals in 
the market within public services, and this was indicative of the reconfiguration of the citizen as consumer (Walsh, 1994). While there had already been attempts to conflate the citizen/patient with the figure of the consumer, as the previous section of this article demonstrated, the introduction of the Patient's Charter did seem to move this in a particular direction. The charter constructed the patient-consumer as an individual concerned with specific rights and service standards. To some extent, this was what patient-consumer groups wanted, as many of these organisations believed that patients should speak for themselves, not through proxies. The Patient's Charter, with its focus on the individual, appeared to provide a tool for patients to demand better services. Yet the fear expressed by groups like ACHCEW was that by focusing on the individual the Patient's Charter set aside more collective concerns, such as addressing health inequalities. Unlike the government, some patient organisations were concerned with the rights of patients, not just the rights of the patient. Of course, there were tensions here with the emphasis placed on individual empowerment by groups like the $\mathrm{CoH}$. However, the College's interest in issues such as health inequalities, waiting lists and the fate of patients in 'Cinderella' services suggests that they (and other patient groups) viewed consumerism as a way of addressing issues of collective, as well as individual, concern.

\section{The patient-consumer under New Labour}

The growing role of the state in shaping discussions about what it meant to be a patient-consumer can also be seen in the development of health policy from 1997 onwards. Although the internal market was abolished under New Labour, other devices, such as the Patient's Charter, were initially retained, albeit in a revised format (Greener, 2003; Forster and Gabe, 2008). The introduction of the NHS Plan in 2000 marked a more significant shift in health policy based on the principles of increased patient choice and voice (Department of Health, 2000). These principles had important implications for the ongoing construction of the patient as consumer. Political support for patient and public involvement was bolstered through mechanisms such as the Health and Social Care Act (2001), which made it a statutory obligation for organisations providing health and social services to involve individuals using these. As a result, there was a proliferation in the number of statutory and quasi-statutory bodies tasked with representing patients. The CHCs were scrapped in 2003 and replaced with a whole host of new organisations (Baggott, 2005). These included the Patient Forums, which took on some of the work of the CHCs; Overview and Scrutiny Committees who had the right to ask for information about how local needs were being addressed; and the Patient Advisory Liaison Service (PALS), which provided 'on-the-spot' advice to patients within NHS Trusts. At the national level, the Commission for Patient and Public Involvement in Health (CPPIH) was established to represent the views of Patients' Forums and patient organisations to government. 
The creation of such a large range of bodies to put forward patients' opinions would seem to constitute significant support for the idea of greater patient involvement, but the very number of these organisations has raised concerns. Milewa points out that the greater emphasis placed on mechanisms for patient participation does not necessarily mean that these are an effective way of increasing patient voice (Milewa, 2004). The patient voice, at both the local and the national level, appears to have become increasingly fragmented. New systems of patient involvement have been criticised for their complexity and lack of coherence (Baggott, 2005), something which was exacerbated by the abolition of the Patient Forums and the CPPIH in 2008. Patient Forums were replaced by Local Involvement Networks (LINks), which had similar functions to the forums but few real powers. Hogg suggests that LINks lack clear systems to guarantee their independence and accountability, and may not be sustainable in the long term (Hogg, 2009). The removal of the CPPIH has also resulted in the absence of a national-level organisation for the representation of patients, something which has been seen as enhancing the government's influence over how public involvement is managed (Forster and Gabe, 2008).

Indeed, it is striking that the growth of patient groups seen in recent years has taken place within the quasi-statutory sector, something which could be regarded as evidence for an enhanced role for government in deciding who speaks for the patient-consumer. There is a long tradition of the state setting up bodies to act as consumer advocates, as in the case of the establishment of the CHCs in the 1970s, but the proliferation of participatory mechanisms under New Labour has resulted in a fragmentation of the sector, to the extent that it is now difficult to discern who actually acts for the patient-consumer at the national level. Independent patient-consumer groups, such as the Patients Association and Which? are still present and active, critiquing government policy on issues of both individual and collective concern, such as the delivery of care for the elderly and the provision of more choice within healthcare (Patients Association, 2009; Which?, 2005). Yet it is unclear precisely what role these organisations play in the participatory framework that operates within the NHS and in health policy more widely.

Such a development has had an impact on the ongoing construction of the patient-consumer. The New Labour vision of the patient-consumer centres on patient choice: on choice of hospital; on choosing a healthy lifestyle and so on (Department of Health, 2004, 2007, 2008, 2009). There is some evidence to suggest that patients do want more choice (Richards and Coulter, 2007), but other studies have revealed greater ambivalence about choice in healthcare (Clarke et al., 2006). What is more, some researchers have detected unease among patients about using the term 'consumer' in the context of health. Clarke has even questioned the extent to which patients consider themselves to be 'consumers', contending that some patients actively refused to be labelled in this way (Clarke, 2007). Patients, he 
suggested, rarely thought of themselves as customers or consumers (Clarke and Newman, 2007).

\section{Conclusion}

That patients themselves should reject the notion that they are 'consumers' seems extraordinary given the numerous attempts highlighted by this article over the last 40 years to construct the patient as consumer. Yet there was, and still is, considerable uncertainty about using the term consumer in the context of health. This has been expressed by numerous policy analysts from the 1970 s onwards. Stacey branded the idea of the health service consumer a sociological 'misconception' in 1978 (Stacey, 1978). Winkler argued that it was inappropriate to describe patients as 'customers' in the 1980s (Winkler, 1987). Shackley and Ryan raised issues with defining patients as consumers in the 1990s, because they saw health care as an imperfect market where consumer sovereignty was limited (Shackley and Ryan, 1994). And in the twenty-first century, many academics continue to highlight problems with applying notions of consumerism to health, surrounding issues such as the persistent information and power gap between doctors and patients, and the limitations of patient choice (for example, Greener, 2003; Clarke and Newman, 2007). In part, this is a reflection of the 'pejorative' meaning that has become attached to consumerism and thus the consumer (Hilton, 2008). Consumerism today is often associated with selfish individuals accumulating more material possessions but, as Hilton and others have pointed out, consumerism was also a political movement. Consumerism was about pursuing basic needs as well as luxuries, something that can be seen in the involvement of consumer groups in debates about the provision of public services in the UK, and also the expansion of a global consumer movement that took on wider issues such as those surrounding poverty, the environment and access to pharmaceutical drugs (Hilton, 2003, 2009). Closer to home, as this article has demonstrated, the notion of the patient-consumer allowed patient groups to advance particular concerns about the autonomy of patients; their ability to have some say in their own treatment; their collective role in the management and development of health services; their ability to exercise some choice and so on. But it is also clear that the patient-consumer was a figure that various governments could use to advance their own view of how healthcare should be delivered, organised and experienced. The patient-consumer was, and remains, a constructed figure: something onto which both government and patient groups were able to project their ideas.

The mutability of the patient-consumer raises the question of agency, and the extent to which patient-consumers shaped themselves, or were shaped by others. Analysis of the consumer has long been concerned with such issues: consumers have been seen as dupes, manipulated by commercial agencies, but 
also as self-defining actors who use consumer goods in self-knowing ways (Miller and Rose, 1997; Shaw and Aldridge, 2003; Gabriel and Lang, 2006). Similar debates have taken place around the figure of the patient, with some historians seeing the patient as an identity created by doctors (Armstrong, 1984); others as an individual who was able to exercise agency within the medical encounter (Porter, 1985). It is, of course, possible for patients and consumers to be both constructed by others and constructed by themselves, and the bringing together of the figure of the patient and the figure of the consumer, as this article has suggested, involved elements of both construction and self-construction. Some ideas about what it meant to be a patient-consumer came from patient-consumer groups, such as the importance of patients' rights and their expression through charters. But a range of different groups and actors, including the state, were involved in constructing the patient as consumer, and ideas about what it meant to be a patient-consumer also changed over time.

Indeed, the intervention of the state was to prove crucial for the construction of the patient-consumer and the relative role played by patient groups in this process. The patient-consumer may have largely originated with patient groups in the 1960s, but as different governments began to pursue consumerist policies within health, voluntary organisations increasingly lost control of the agenda. The introduction of a market-based understanding of consumerism from the late 1980 s onwards - and the attention paid to individual patientconsumer, rather than issues of more collective concern - was a development which came from the state, not from patient groups. By the 20oos, quasistatutory organisations representing the patient-consumer within the NHS had multiplied: a development which displaced some long-established patientconsumer groups as the main advocates for the patient-consumer. Paradoxically, as government attention to the patient-consumer increased, the actual role played by independent patient-consumer groups seemed to diminish.

The shifting meanings ascribed to the patient-consumer, and the changing nature of the groups representing their concerns, should, therefore, raise doubts about any authority that claims to know what patient-consumers 'really' want.

\section{References}

6, P. (2003), 'Giving consumers of British public services more choice: what can be learned from recent history?', Journal of Social Policy, 32: 2, 239-70.

Anon (1961), 'Patients as consumers: wants and needs', The Lancet, 927-28.

Anon (1962), 'Patients as consumers', The Lancet, 957.

Armstrong, D. (1984), 'The patient's view', Social Science and Medicine, 18: 9, 737-44.

Association of Community Health Councils for England and Wales (ACHCEW) (1986), Patients' Charter, London: ACHCEW.

Association of Community Health Councils for England and Wales (ACHCEW) (1996), The Patients' Agenda: What the Patient's Charter Leaves Out - the Rights You Don't Yet Have in the NHS, London: ACHCEW.

Baggott, R. (2005), 'A funny thing happened on the way to the forum? Reforming patient and public involvement in the NHS in England', Public Administration, 83: 3, 533-51. 
Baggott, R. and Forster, R. (2008), 'Health consumer groups and patients' organisations in Europe: towards a comparative analysis', Health Expectations, 11: 89-94.

Brewer, J. and Trentmann, F. (2006), 'Introduction: space, time and value in consuming cultures', in J. Brewer and F. Trentmann (eds.), Consuming Cultures, Global Perspectives: Historical Trajectories, Transnational Exchanges, Oxford: Berg, pp. 1-13.

Cartwright, A. (1964), Hospital Relations and Human Care, London: Routledge \& Kegan Paul.

Clarke, J. (2007), “It's not like shopping”: citizens, consumers and the reform of public services', in M. Bevir and F. Trentmann (eds.), Governance, Consumers and Citizens: Agency and Resistance in Contemporary Politics, Basingstoke: Palgrave, pp. 97-118.

Clarke, J. and Newman, J. (2007), 'What's in a name? New Labour's citizen-consumers and the remaking of public services', Cultural Studies, 21: 738-57.

Clarke, J., Smith, N. and Vidler, E. (2006), 'The indeterminacy of choice: political, policy and organisational implications', Social Policy and Society, 5:3, 327-36.

College of Health [CoH] (1984), First Annual Report, London: College of Health.

Consumers' Association (1980), The Which? Guide to Your Rights, London: Consumers' Association.

Crinson, I. (1998), 'Putting patients first: the continuity of the consumerist discourse in health policy from the radical right to New Labour', Critical Social Policy, 18: 2, 227-39.

Deakin, N. (1995) 'The perils of partnership: the voluntary sector and the state 1945-1992', in J. Davis Smith, C. Rochester and R. Hedley (eds.), An Introduction to the Voluntary Sector, London: Routledge, pp. 40-65.

Department of Health (1989), Working for Patients, London: HMSO.

Department of Health (1991), The Patient's Charter, London: HMSO.

Department of Health (2000), NHS Plan: A Plan for Investment, A Plan for Reform, London: The Stationery Office.

Department of Health (2004), Choosing Health: Making Healthy Choices Easier, London: The Stationery Office.

Department of Health (2006), Our Health, Our Care, Our Say, London: HMSO.

Department of Health (2007), Choice Matters: Putting Patients in Control, London: HMSO.

Department of Health (2008), NHS Choices: Delivering for the NHS, London: HMSO.

Department of Health (2009), NHS Constitution, London: HMSO.

Department of Health and Social Security [DHSS] (1973), Report of the Committee on Hospital Complaints Procedure, London: HMSO.

Digby, A. (1994), Making a Medical Living: Doctors and Patients in the English Market, 1720-1911, Cambridge: Cambridge University Press.

Fielding, S. (2003), The Labour Governments 1964-1970, Volume 1: Labour and Cultural Change, Manchester: Manchester University Press.

Forster, R. and Gabe, J. (2008), 'Voice or choice? Patient and public involvement in the National Health Service in England under New Labour', International Journal of Health Services, 38: 2, 333-56.

Gabriel, Y. and Lang, T. (2006), The Unmanageable Consumer, London: Sage.

Gorsky, M. (2007), Memorandum submitted to the Health Select Committee inquiry into Public and Patient Involvement in the NHS, January 2007, http://www.historyandpolicy. org/papers/policy-paper-40.html, accessed 06/10/09.

Gorsky, M. (2008), 'Community involvement in hospital governance in Britain: evidence from before the National Health Service', International Journal of Health Services, 38: 4, 751-71.

Gorsky, M., Mohan, J. and Willis, T. (2006), Mutualism and Health Care: Hospital Contributory Schemes in Twentieth Century Britain, Manchester: Manchester University Press.

Griffiths, R. (1983), 'NHS Management Enquiry', reproduced in S. Harrison (1994), National Health Service Management in the 1980s, Aldershot: Avebury.

Greener, I. (2003), 'Who choosing what? The evolution of the use of "choice" in the NHS and its importance for New Labour', in C. Bochel, N. Ellison and M. Powell (eds.), Social Policy Review 15: UK and International Perspectives, Bristol: The Social Policy Press, pp. 49-68.

Greener, I. (2009), 'Towards a history of choice in UK health policy', Sociology of Health and Illness, 31: 3, 309-24. 
Greener, I. and Powell, M. (2008), 'The evolution of choice policies in UK housing, education and health policy', Journal of Social Policy, 38: 1, 63-81.

Harrison, S. (1994), National Health Service Management in the 1980s, Aldershot: Avebury.

Hazelgrove, J. (2002), 'The old faith in the new science: the Nuremberg code and human experimentation ethics in Britain, 1946-73', Social History of Medicine, 15: 1, 109-35.

Hilton, M. (2003), Consumerism in Twentieth Century Britain: The Search for a Historical Movement, Cambridge: Cambridge University Press.

Hilton, M. (2009), Prosperity for All: Consumer Activism in an Era of Globalisation, Ithaca, NY: Cornell University Press.

Hilton, M. (2008), 'The banality of consumption', in F. Trentmann and K. Soper (eds.), Citizenship and Consumption, Basingstoke: Palgrave.

Hodgson, H. (1963), 'Medical ethics and controlled trials', letter to the British Medical Journal, 1339-40.

Hogg, C. (1999), Patients, Power and Politics: From Patients to Citizens, London: Sage.

Hogg, C. (2009), Citizens, Consumers and the NHS: Capturing Voices, Basingstoke: Palgrave.

Irvine, R. (2002), 'Fabricating "health consumers" in health care politics', in S. Henderson and A. Petersen (eds.), Consuming Health: The Commodification of Health Care, London: Routledge, pp. 31-47.

Jenner, M. and Wallis, P. (eds.) (2007), Medicine and the Market in England and Its Colonies, c.1450-c.1850, Basingstoke: Palgrave.

Johnson, M. L. (1977), 'Patients: receivers or participants?', in K. Barnard and K. Lee (eds.), Conflicts in the National Health Service, London: Croom Helm, pp. 72-98.

Le Grand, J. (1991), 'Quasi-markets and social policy', The Economic Journal, 101: 408, 1256-67.

Milburn, A. (2001), Speech by the Rt Hon Alan Milburn MP, Secretary of State, to the Fabian Society, 21 October 2001, http://www.dh.gov.uk/en/News/Speeches/Speecheslist/ DH_4000444, accessed 09/03/09.

Milewa, T. (2004), 'Local participatory democracy in Britain's health service: innovation or fragmentation of a universal citizenship?', Social Policy and Administration, 38: 3, 240-52.

Miller, P. and Rose, N. (1997), 'Mobilizing the consumer: assembling the subject of consumption', Theory, Culture and Society, 14: 1, 1-36.

National Consumer Council (1983), Patients' Rights, London: National Consumer Council.

Pappworth, M. (1962), 'Human guinea pigs: a warning', Twentieth Century, 171: 67-75.

Patients Association (1974), Can I Insist? London: Patients Association.

Patients Association (2009), Patients Not Numbers, People Not Statistics, London: Patients Association.

Perkin, H. (1990), The Rise of Professional Society: England Since 1880, London: Routledge.

Pickstone, J. (2000), 'Production, community and consumption: the political economy of twentieth-century medicine', in R. Cooter and J. Pickstone (eds.), Medicine in the Twentieth Century, Amsterdam: Harwood, pp. 1-19.

Political and Economic Planning [PEP] (1961), Family Needs and the Social Services, London: George Allen \& Unwin.

Porter, R. (1985), 'The patient's view: doing medical history from below', Theory and Society, 14: 2, 175-98.

Research Institute for Consumer Affairs (RICA) (1963), General Practice: A Consumer Commentary, London: RICA.

Richards, N., and Coulter, A. (2007), Is the NHS Becoming More Patient Centred? Trends from the National Surveys of NHS Patients 2002-07, Oxford: Picker Institute.

Rigge, M. (1995), 'Self-help and empowerment in health', in G. Dench, T. Flower and K. Gavron (eds.), Young at Eighty: The Prolific Life of Michael Young, Manchester: Carcanet Press, pp. 39-41.

Seale, C. (1993), 'The consumer voice', in B. Davey and J. Popay (eds.), Dilemmas in Health Care, Buckingham: Open University Press, pp. 64-80.

Self Health (1983), Issue 1. 
Shackley, P. and Ryan, M. (1994), 'What is the role of the consumer in health care?', Journal of Social Policy, 23: 4, 517-41.

Shapely, P. (2006), 'Tenants arise! Consumerism, tenants and the challenge to council authority in Manchester, 1968-92', Social History, 31: 1, 60-78.

Shaw, I. and Aldridge, A. (2003), 'Consumerism, health and social order', Social Policy and Society, 21: 35-43.

Smith, G. (2005), 'The rise of the "new consumerism" in health and medicine in Britain, c.1948-1989', in J. Burr and P. Nicholson (eds.), Researching Health Care Consumers: Critical Approaches, Basingstoke: Palgrave.

Stacey, M. (1974), 'Consumer complaints procedures in the British National Health Service', Social Science and Medicine, 8: 429-35.

Stacey, M. (1978), 'The health service consumer: a sociological misconception', The Sociological Review Monograph, 22: 194-200.

Stacey, M. (1999), 'The NHS complaints procedure three years on', Modern Records Centre, Private Papers of Margaret Stacey, MSS 184, Box 2, University of Warwick.

Tomes, N. (2006), 'Patients or healthcare consumers? Why the history of contested terms matters', in C. Rosenberg (ed.), History and Health Policy in the US: Putting the Past Back In, New Brunswick, NJ: Rutgers University Press, pp. 83-110.

Trentmann, F. (2006), 'The modern genealogy of the consumer: meanings, identities and political synapses', in F. Trentmann and J. Brewer (eds.), Consuming Cultures, Global Perspectives: Historical Trajectories, Transnational Exchanges, Oxford: Berg, pp. 19-69.

van der Zeijden, A. (2000), 'The patient rights movement in Europe', Pharmacoeconomics, 18: 7-13.

Walsh, K. (1994), 'Citizens, charters and contracts', in R. Keat, N. Whitely and N. Abercrombie (eds.), The Authority of the Consumer, London: Routledge, pp. 189-206.

Webster, C. (1996), The Health Services Since the War Volume II: Government and Health Care - The National Health Service 1958-1979, London: TSO.

Which? (2005), Which Choice? Health, London: Which?

Wilde, S. (2009), 'Truth, trust, and confidence in surgery, 1890-1910: patient autonomy, communication and consent', Bulletin of the History of Medicine, 83: 302-30.

Winkler, F. (1987), 'Consumerism in health care: beyond the supermarket model', Policy and Politics, 15: 1, 1-8.

Wood, B. (2000), Patient Power? The Politics of Patients' Associations in Britain and America, Buckingham: Open University Press.

Young Papers (1983), 'A body designed to increase trust between doctor and patient', Private Papers of Michael Young, YUNG/6/10/1, Churchill College, Cambridge.

Young Papers (1986), 'Information and choice for patients', by Marianne Rigge, Private Papers of Michael Young, YUNG/6/10/3, Churchill College, Cambridge.

Young, M. (1989) 'The College of Health's view', in D. Green et al., The NHS Reforms: Whatever Happened to Consumer Choice? London: Institute of Economic Affairs.

Young, M. (1991), Comments on the Patient's Charter to David Brindle and Malcolm Dean at The Guardian, Private Papers of Michael Young, YUNG/6/10/7, Churchill College, Cambridge. 